Nahornyi la. Manual therapy as the physical rehabilitation means during ataxia. Theory and Methods of Physical education and sports. 2019; 1: 79-83 DOI:10.32652/ tmfvs.2019.1.79-83
Нагорний Я. Мануальна терапія як засіб фізичної реабілітації при атаксіях. Теорія і методика фрізичного виховання і спорту. 2019; 1: 79-83 DOI:10.32652/tmfvs.2019.1.79-83

\title{
МАНУАЛЬНА ТЕРАПІЯ ЯК ЗАСІБ ФІЗИЧНОЇ РЕАБІЛІТАЦЇ̈ ПРИ АТАКСІЯХ
}

\section{Ярослав Нагорний}

Національний університет фізичного виховання і спорту України, Київ, Україна

\begin{abstract}
Анотація. Атаксія - складний стан, який може бути викликаний як психологічним стресом, так і фрізичним ушкодженням тіла людини, а також може бути обумовлений генетичним захворюванням. Мануальна терапія як засіб фрізичної реабілітації- це спосіб лікування захворювань хребта, суглобів, м'язів, зв'язок, судинно-нервових структур, а також вертеброгенних захворювань внутрішніх органів за допомогою ручного впливу, який давно привернув до себе увагу завдяки ефективності його застосування у процесі реабілітації при атаксіях. Аналізуючи дані вітчизняної та зарубіжної наукової літератури, ми прийшли до висновку, що засоби мануальної терапії мають надзвичайно важливе значення у фрізичній реабілітації, що і визначило мету нашого дослідження. Мета. Обгрунтувати ефрективність застосування мануальної терапії, як засобу фрізичної реабілітації при атаксіях. Методи. Аналіз та узагальнення даних літературних джерел та передового міжнародного і вітчизняного досвіду. Результати. Мануальною терапією може займатись лише спеціаліст, котрий знає клінічну анатомію і патологію хребта, зв'язок опорно-рухового апарату з іншими функціональними системами організму, пройшов відповідну підготовку і вміє застосовувати методи мануальної діагностики і терапії. Мануальна терапія як складова процесу фрізичної реабілітації чинить оздоровчий вплив на організм і повертає людину до нормального життя.

Цей ефрект полягає у більш швидкому протіканні відновних процесів завдяки не лише механічній дії, а й впливу безпосередньо на центральну нервову систему, адже в процесі реабілітації між пацієнтом та лікарем швидше виникають психологічні зв'язки, у пацієнтів спостерігається не лише відновлення втрачених функцій, а і швидші процеси відновлення соціальних взаємозв'язків, що обумовлено психологічною атмосферою, сформованою в процесі мануальної терапії. Ці та інші фрактори вказують на доцільність застосування засобів мануальної терапії в процесі відновлення після атаксій.
\end{abstract}

Ключові слова: мануальна терапія, атаксії, фрізична реабілітація.

\section{Iaroslav Nahornyi}

\section{MANUAL THERAPY AS THE PHYSICAL REHABILITATION MEANS DURING ATAXIA}

Abstract. Ataxia is a complex condition that can be caused both by psychological stress and physical damage to the human body. It may be due to genetic disease as well. Manual therapy as a means of physical rehabilitation is a method of treating diseases of the spine, joints, muscles, ligaments, vascular nervous structures, as well as vertebrogenic diseases of the internal organs with the help of manual influence, which has long attracted attention due to the effectiveness of its use in the process of rehabilitation during ataxia. Analyzing the data of national and foreign scientific literature, we came to the conclusion that the means of manual therapy are extremely important in physical rehabilitation, which determined the objective of our study. Objective. To substantiate the effectiveness of manual therapy usage as a means of physical rehabilitation during ataxia. Methods. Analysis and generalization of data of literary sources and advanced international and national experience. Results. Only a specialist who knows the clinical anatomy and pathology of the spine, the link of the locomotor system with other functional body systems, has received respective training and is able to use manual diagnostic and therapeutic methods can practice manual therapy. Manual therapy as part of the process of physical rehabilitation has a health related effect on the body and returns a person to normal life.

This effect consists in faster course of restorative processes due to both the mechanical action and the direct impact on the central nervous system, as in the process of rehabilitation the psychological connections between the patient and the physician tend to occur faster. The recovery of lost functions as well as faster processes of restoring social interactions due to the psychological atmosphere formed in the process of manual therapy are usually observed in the patients. These and other factors indicate the expediency of the use of manual therapies in the process of recovery after ataxia.

Keywords: manual therapy, ataxia, physical rehabilitation.

Вступ. Медична сфера та сфера відновлення після різноманітних захворювань та травм - надзвичайно динамічна, вона безперервно та стрімко розвивається відповідно до вимог сучасного суспільства та з огляду на появу все більшої кількості засобів терапії. На сьогодні фізична реабілітація зробила крок у своєму прогресі набагато далі, ніж можна собі уявити. Робопротези, штучний інтелект, інші техногенні ідеї інженерів дивують нас кожного дня. Але не варто забувати про просту та геніальну річ: будь-яка проблема у стані здоров'я людини повністю пов'язана 3 коректним функціонуванням центральної нервової системи (ЦНС). 
Атаксія - це стан, викликаний порушенням їі діяльності, що проявляється у вербальних та рухових розладах. Фізична реабілітація у таких випадках є невід'ємною частиною успішного лікування та повернення організму до стану оптимального функціонування. Досить дієвим та ефективним засобом фізичної реабілітації при атаксіях є мануальна терапія.

Проблему фізичної реабілітації досліджено у працях багатьох учених [1-3, 5-8]. Проте мануальну терапію та атаксію у працях цих учених розглянуто лише частково.

Велику роль у розвитку мануальної терапії в Європі відіграв професор-фізіотерапевт Дж. Менне. Його учень Дж. Сиріах, видатний клініцист, видав «Підручник ортопедичної медицини» (1954р.). Новітні методики мануальної медицини розробив англійський невропатолог А. Стоддард (1959р.), який почав з остеопатії. Французький професор Р. Менне розробив нові методи маніпуляцій на хребті і в 1970 р. запропонував ввести курс мануальної терапії на медичному факультеті в Парижі [8].

Мануальна терапія як засіб фізичної реабілітації - це спосіб лікування захворювань хребта, суглобів, м'язів, зв'язок, судинно-нервових структур, а також вертеброгенних захворювань внутрішніх органів за допомогою ручного впливу. Нею може займатись лікар, котрий знає клінічну анатомію і патологію хребта, його зв'язки з іншими органами і системами, пройшов відповідну підготовку і вміє застосовувати методи мануальної діагностики [1, 6, 11].

Не зважаючи на широку популярність та високу ефективність зазначеного засобу фізичної реабілітації при атаксіях, у ході аналізу літературних джерел ми не знайшли грунтовного розгляду зазначеної проблеми, що і зумовило актуальність даного дослідження зазначеного питання.

Мета дослідження - обгрунтувати ефективність застосування мануальної терапії як засобу фізичної реабілітації при атаксіях.

Методи дослідження: аналіз та узагальнення передового зарубіжного та вітчизняного досвіду.

Результати дослідження та їх обговорення. Атаксія (з грец. - розлад координації довільних рухів) спостерігається при деяких захворюваннях нервової системи [10]. Вона характеризується труднощами в утриманні рівноваги, дезорганізованими незграбними рухами. Оскільки координація рухів здійснюється за допомогою злагодженого функціонування різних відділів нервової системи, порушення на одному 3 рівнів може проявлятися у вигляді атаксії. Лікар під час обстеження пацієнта може встановити, чи є атаксія наслідком ушкодження головного або спинного мозку, периферичних нервів. Найбільш часто вона розвивається внаслідок ураження мозочка [10].

Основними симптомами атаксії є:
- порушення рівноваги;

- порушення ходьби, які можуть включати: ходьбу з широко розставленими ногами, розгойдування з боку в бік, неможливість ходьби по прямій лінії, падіння внаслідок нестійкості;

- незграбні рухи кінцівок;

- тремтіння (тремор), що посилюється під час наближення до кінцевої мети рухового акту (може включати руки, ноги, голову або все тіло);

- порушення мовлення (ускладнене мовлення);

- офтальмологічні порушення, які проявляються двоїнням або нечіткістю зору;

- запаморочення [10].

Головною причиною виникнення атаксії як такої є неврологічний синдром, а не певне захворювання. Існує безліч можливих причин, включаючи такі:

- ушкодження головного мозку внаслідок пухлини, інсульту, травми голови, інфекцій тощо;

- дефіцит вітамінів, наприклад, низький рівень вітаміну $\mathrm{B}_{1}, \mathrm{~B}_{12}$ або $\mathrm{E}$;

- вплив деяких препаратів або токсинів, таких як фенітоїн, карбамазепін, барбітурати, седативні засоби, деякі антибіотики, препарати літію, аміодарон, алкоголь;

- аутоімунні стани, наприклад, розсіяний склеро3, імунна відповідь на пухлину, запалення судин головного мозку (васкуліти), целіакія;

- метаболічні захворювання, наприклад, дисфункція щитоподібної залози, низький рівень цукру в крові;

- нейродегенеративні захворювання, при яких відбувається загибель нервових клітин, наприклад, мультисистемна атрофія (МСА), спиноцеребральні атаксії (СЦА) тощо;

- спадкові або генетичні захворювання [10].

Для діагностики атаксії лікареві необхідно встановити етіологію хвороби, з'ясувати наявність спадкових факторів хворого. Також доцільним є ретельний неврологічний огляд i, за необхідності, додаткові методи обстеження: проведення КТ або МРТ головного мозку і /або МРТ спинного мозку; аналізи крові, сечі; тести на регуляцію артеріального тиску й уродинаміки; обстеження серця; дослідження провідності нервів і електроміографія (ЕНМГ / ЕМГ); нейропсихологічне дослідження; офтальмологічний огляд; генетичне дослідження крові для виключення спадкових причин [10].

Вибір методу лікування залежить від причини атаксії. При розвитку їі на фоні прийому препаратів або токсичних речовин необхідне їх скасування. Аналогічним буде шлях у подоланні причин захворювання у випадку дефіциту вітамінів, при пухлинах, аутоімунних або метаболічних розладах. При деяких спадкових атаксіях доцільно призначати медикаментозну терапію, вітамінотерапію. За відсутності специфічного лікування якість життя пацієнтів з атаксією можна поліпшити за допомогою фізичної, мовної терапії та ерготерапії [10]. 
Актуальність фізичної реабілітації під час боротьби з атаксією полягає в тому, що вона є складовою частиною медичної, соціальної і професійної реабілітації. Сприяє відновленню або компенсації фізичних можливостей та інтелектуальних здібностей, підвищенню функціонального стану організму, поліпшенню фізичних якостей, психоемоційної стійкості і збільшенню адаптаційних резервів організму людини засобами і методами фізичної культури, масажу, фізіотерапії і природних факторів [7]. Вона є невід'ємною частиною процесу відновного лікування пацієнтів 3 атаксіями, а її прямим методом дії виступає мануальна терапія [2, 3, 9].

Лікувальний масаж проводять у формі загального і місцевого масажу ручним (мануальним) чи апаратним методом, або комбінованим, тобто з використанням першого та другого методу. Виконується він масажистом, а також у вигляді самомасажу [5]. Ручний масаж є основним методом, тому що його можна застосовувати у простих умовах, в лікарні і вдома, на ранніх етапах лікування i, що головне, завдяки додатковому відчуттю і візуальному контролю масажиста за реакцією пацієнта на різноманітні прийоми дозволяє диференціювати методику, підвищуючи ефективність. Різновидом ручного лікувального масажу є сегментарнорефлекторний і точковий [5].

Дія сегментарно-рефлекторного масажу грунтується на анатомічно-фізіологічній сегментарній будові тіла, де одні і ті самі сегменти спинного мозку іннервують ділянки шкіри та поверхневі тканини і певні внутрішні органи [3].

Точковий масаж - це механічний вплив на зазвичай біологічно активні точки, які топографічно відповідають проекції нервових стовбурів і судинно-нервових пучків, що проходять у тканинах. Вони відрізняються від оточуючих тканин більшою температурою та електропровідністю, а ïx місцезнаходження визначають за допомогою портативного апарату тобіскоп. Основними прийомами точкового масажу є розтирання, натискання, вібрація, «свердління», які виконують одним чи кількома пальцями або вібраційним апаратом [5].

Складність застосування мануальної терапії може бути наслідком таких причин: технічно неправильні прийоми, проведення грубих маніпуляцій; правильно виконані прийоми за наявності протипоказань [6].

Мануальну діагностику використовують для виявлення заблокованих (нерухомих) сегментів i суглобів, гіпермобільності в сегменті, дисторзій, спондилолістезів, тунельних синдромів, локального набряку, порушення трофіки, тригерних точок [6]. Методики мануальної терапії класифікують таким чином (табл. 1).

Як і будь-який реабілітаційний прийом, мануальна терапія має свої показання та протипоказання, які необхідно обов'язково враховувати під час формування програми реабілітації (табл. 2).
Таблиця 1 - Методики мануальної терапії [6]

\begin{tabular}{|c|c|}
\hline Різновиди впливу & Масажні прийоми \\
\hline $\begin{array}{l}\text { За видом ме- } \\
\text { тодичного при- } \\
\text { йому }\end{array}$ & $\begin{array}{l}\text { - мобілізація - пасивний рух, тракція, } \\
\text { стискання, постізометрична релаксація, } \\
\text { аутомобілізація; } \\
\text { • маніпуляція - поштовх, тракційний по- } \\
\text { штовх; } \\
\text { - комбіновані прийоми }\end{array}$ \\
\hline За об’єктом дії & $\begin{array}{l}\text { - суглобова; } \\
\text { - м'язова }\end{array}$ \\
\hline $\begin{array}{l}\text { За характером } \\
\text { дії }\end{array}$ & $\begin{array}{l}\text { - нецілеспрямована (полісегментна); } \\
\text { - цілеспрямована (моносегментна); } \\
\text { - контактна, оклюзивна, поєднана (з } \\
\text { протитриманням, з підтримкою) }\end{array}$ \\
\hline $\begin{array}{l}\text { За напрямком } \\
\text { руху }\end{array}$ & $\begin{array}{l}\text { - односпрямована (флексія, екстензія, ла- } \\
\text { терофлексія, ротація, аддукція, абдукція); } \\
\text { - комбінована (флексія + латерофлек- } \\
\text { сія + ротація та інші комбінації) }\end{array}$ \\
\hline
\end{tabular}

Таблиця 2 - Методологія застосування мануальної терапії [6]

\begin{tabular}{|c|c|}
\hline Симптоми & Методи лікування \\
\hline Функціональна блокада & $\begin{array}{l}\text { Релаксаційні прийоми - } \\
\text { м'якотканинні техніки } \\
\text { (також використовують- } \\
\text { ся масаж, теплові про- } \\
\text { цедури, акупунктура) }\end{array}$ \\
\hline Локальна гіпермобільність & Мобілізація \\
\hline $\begin{array}{l}\text { Міодистонічно-міодистрофічні } \\
\text { зміни м'язів }\end{array}$ & Маніпуляція \\
\hline $\begin{array}{l}\text { Регіональний постуральний дис- } \\
\text { баланс м'язів }\end{array}$ & $\begin{array}{l}\text { Постізометрична релак- } \\
\text { сація м'язів (ПіРМ) }\end{array}$ \\
\hline $\begin{array}{l}\text { Неоптимальний руховий сте- } \\
\text { реотип }\end{array}$ & $\begin{array}{l}\text { Прийоми аутомобілізації } \\
\text { та аутостабілізації }\end{array}$ \\
\hline \multicolumn{2}{|c|}{ Протипоказання } \\
\hline Абсолютні & Відносні \\
\hline $\begin{array}{l}\text { Гострі запальні захворювання } \\
\text { спинного мозку та його оболонок }\end{array}$ & $\begin{array}{l}\text { Спадкові аномалії роз- } \\
\text { витку }\end{array}$ \\
\hline $\begin{array}{l}\text { Новоутворення хребта, спинно- } \\
\text { го, головного мозку, внутріш- } \\
\text { ніх органів }\end{array}$ & $\begin{array}{l}\text { Корінцевий компресій- } \\
\text { ний синдром }\end{array}$ \\
\hline $\begin{array}{l}\text { Гострий період після травми } \\
\text { хребта та суглобів (або після } \\
\text { операцій) }\end{array}$ & Старечий вік \\
\hline $\begin{array}{l}\text { Захворювання системи крові } 3 \\
\text { геморагічним синдромом }\end{array}$ & Радикуломієлоішемія \\
\hline Анкілоз суглобів & \multirow{5}{*}{ Вагітність більше 3 міс. } \\
\hline $\begin{array}{l}\text { Гострі фази захворювань вну- } \\
\text { трішніх органів }\end{array}$ & \\
\hline Їнфекційні захворювання & \\
\hline $\begin{array}{l}\text { Специфічні та неспецифічні про- } \\
\text { цеси хребта та суглобів (остео- } \\
\text { мієліт, гостра фаза ревматизму, } \\
\text { туберкульозний спондиліт, бру- } \\
\text { цельозний спондиліт) }\end{array}$ & \\
\hline $\begin{array}{l}\text { Метаболічні порушення, що су- } \\
\text { проводжуються остеопорозом }\end{array}$ & \\
\hline
\end{tabular}


Атаксія - це порушення координації рухів, не пов'язане з м'язовою слабкістю. Стан впливає на координацію рухів верхніх і нижніх кінцівок, ходи, а також іноді елементи атаксії спостерігають під час дихання і мовлення. Фізична реабілітація за допомогою мануальної терапії є найточнішим i найменш травматичним методом повернення людини до звичного життя [4].

Рухові аналізатори людини контролює ЦНС, яка передає й обробляє інформацію від рецепторів опорно-рухового апарату і бере участь в організації і реалізації координованих рухів [4].

Як і інші аналізатори, м'язовий аналізатор складається 3 трьох відділів: сприймаючого (периферичного), провідникового і кіркового. Рецептори сприйняття розташовані в м'язах, сухожиллях, зв'язках, капсулах суглобів, окісті. Альфа- і гамма-мотонейрони спинного мозку, отримуючи регулюючі впливи від структур головного мозку, надсилають команди до м'язів. Ці команди коригуються пропріорецепторами м'язів, сухожиль, капсул суглобів. Регуляція рухів забезпечується спільною діяльністю всіх нервових структур [4].

Безумовно, процес управління рухами складніший будь-якої схеми: він включає системи регуляції м'язового тонусу, збереження рівноваги тіла, поточне й аварійне нервово-м'язове забезпечення положень і рухів тіла тощо [4].

Освоєння і вдосконалення рухів - складне, багатопланове завдання. У цілісному руховому акті всі характеристики руху взаємопов'язані. Під час оволодіння та вдосконалення рухів необхідно виходити не тільки з біомеханічної доцільності, а й обов'язково враховувати майбутні кінематичні можливості [4].

У міру того як спортсмен, опановуючи спортивну техніку, повинен вдосконалювати м'язове відчуття, гостроту зорового і слухового сприйняття, відчуття рівноваги і специфічні якості, пов'язані зі спеціалізованою змагальною діяльністю, так i під час навчання та відновлення порушених рухів у пацієнтів з атаксіями необхідне спеціальне тренування аналізаторів, яким належить провідна роль у даній руховій діяльності. Без цього будьяка біомеханічна доцільна техніка рухів перетво- рюється у формальні рухові акти і не приведе до стабільних результатів [4].

Основою мануальної терапії є вчення про блокування рухів, тобто функціональну блокаду, під якою розуміють втрату рухів у хребцево-руховому сегменті. Мануальна терапія є ніби зв'язувальною ланкою між рефлексотерапією і лікувальною гімнастикою як видами специфічного лікування порушень моторики. Крім того, мануальна процедура - це ще й психотерапія, яка включає тактильний та вербальний контакти між лікарем та пацієнтом. Між пацієнтом та мануальним терапевтом виникають тісніші психологічні контакти, ніж між звичайним лікарем та пацієнтом. Це обумовлено тактильним контактом.

У повсякденному житті існує чіткий етикет відносно дотиків. Крім рукостискань люди, які не перебувають у родинних стосунках, можуть торкатися плеча або ліктя один одного. Дотики можливі у спортивних змаганнях і в танцях, але там вони функціональні і не несуть психологічного навантаження. Якщо одна людина дозволяє іншій торкатися її тіла, зокрема зон, близьких до геніталій (сідниці, пахові складки), вона цим самим психологічно підсвідомо віддає себе під їі владу. Коли цей бар'єр, який є підсвідомим, пацієнтом пройдений, то між ним і мануальним терапевтом складається особливий тип довірливих відносин.

Висновки. Мануальна терапія як засіб фізичної реабілітації при атаксіях виступає вирішальним фактором успішної фізичної діяльності організму пацієнтів у процесі реабілітаційного періоду. Це комплекс спеціальних прийомів діагностики та лікування, які виконуються винятково руками лікаря, який пройшов спеціальну підготовку, без застосування інструментів. Мета мануальної терапії - діагностика й усунення функціональних порушень, викликаних атаксіями, передовсім, опорно-рухового апарату, що охоплюють основну частину тіла людини, а також інших систем, пов'язаних між собою, і підтримують динамічну рівновагу, що і визначає здоров'я.

Конфлікт інтересів. Автор заявляє, що відсутній будь-який конфлікт інтересів.

\section{Література}

1. Алексанина СС, редактор. Медицинская реабилитация: учеб. пособие. Всерос. центр экстрен. и радиац. медицины им. А. М. Никифорова МЧС России. - Санкт-Петербург: Политехника-сервис; 2014. 184 с.

2. Воронін ДМ, Павлюк ДМ. Фізична реабілітація при захворюваннях нервової системи : навч. посіб. Хмельницький: ХНУ; 2011. 143 с.

3. Дубровский ВИ. Лечебная физическая культура (кинезитерапия): учеб. для студ. высш. учеб, заведений. Москва: Гуманит. изд. центр ВЛАДОС; 2001. 608 с.

4. Козявкин ВИ, Сак НН, Качмар ОА, Бабадаглы МА. Основы реабилитации двигательных нарушений по методу Козявкина. Львів: НВФ «Українські технології»; 2007. 192 с.

5. Магльований А, Магльована Г, Мухін Г. Основи фрізичної реабілітації. Львів: Ліга-Прес; 2006.150 с.

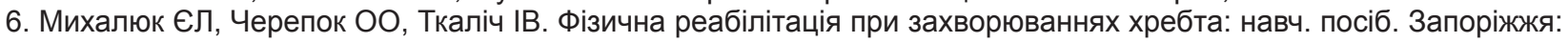
ЗДМУ; 2016. 90 с. 
7. Попов СН, редактор. Физическая реабилитация: учебник для студентов высших учебных заведений, обучающихся по Государственному образовательному стандарту 022500 «Физическая культура для лиц с отклонениями в состоянии здоровья» (Адаптивная физическая культура). Ростов-на-Дону: Феникс, 2005. 608 с.

8. Примачок ЛЛ. Історія медицини та реабілітації: навч. посіб. Ніжин: НДУ ім. М. Гоголя; 2014. 104 с.

9. Elizabeth Cassidy Using interpretative phenomenological analysis to inform physiotherapy practice: An introduction with reference to the lived experience of cerebellar ataxia. Physiotherapy Theory and Practice. An International Journal of Physical Therapy [Internet]. 2011 [Cited 2019 Mar. 17]; 27 (4). 263-77.

10. International Parkinson and Movement Disorder Society (MDS). Атаксия [Інтернет] [цитовано 2019 Бер.17] Доступно на: https://www.movementdisorders.org/MDS-Files1/Education/Patient-Education/Ataxia/pt-Handouts-Ataxia-Russian-v1.pdf

11. Jonathan F. Marsden. Cerebellar ataxia. Balance. Gait, and Falls; 2018: 261-281.

\section{Literature}

1. Aleksanina SS. Medical rehabilitation: teaching guide. Vserossiysky tsentr ekstrennoy i radiatsionnoy meditsiny imeni A. M. Nikiforova MCS Rossiyi. - Saint Petersburg: Politekhnika-servis; 2014. 184 p.

2. Voronin DM, Pavliuk DM. Physical rehabilitation during nervous system diseases : teaching guide. Khmelnitskyi: KNU; 2011. 143 p.

3. Dubrovsky VI. Physical therapy (kinesitherapy): textbook for students of higher education institutions. Moscow: Gumanitarny izdatelsky tsentr VLADOS; 2001. 608 p.

4. Kozyavkin VI, Sak NN, Kachmar OA, Babadagly MA. Bases of rehabilitating motor disorders by Kozyavkin's method. Lviv: NVF «Ukrainski tekhnolohii»; 2007. 192 p.

5. Mahliovanyi A, Mahliovana H, Mukhin H. Physical rehabilitation bases. Lviv: Liha-Pres; 2006.150 p.

6. Mykhaliuk IL, Cherepok OO, Tkalich IV. Physical rehabilitation during spine diseases: teaching guide. Zaporizhzhia: ZDMU; 2016. 90 p.

7. Popov SN, editor. Physical rehabilitation: textbook for higher education institution students studying according to State education standard 022500 «Physical culture for patients with health deviations» (Adaptive physical culture). Rostovon-Don: Feniks, 2005. 608 p.

8. Prymachok LL. History of medicine and rehabilitation: teaching guide. Nizhyn: NDU imeni. M. Hoholia; 2014.104 p.

9. Elizabeth Cassidy Using interpretative phenomenological analysis to inform physiotherapy practice: An introduction with reference to the lived experience of cerebellar ataxia. Physiotherapy Theory and Practice. An International Journal of Physical Therapy [Internet]. 2011 [Cited 2019 Mar. 17]; 27 (4). 263-77.

10. International Parkinson and Movement Disorder Society (MDS). Атаксия [Інтернет] [цитовано 2019 Бер.17] Доступно на: https://www.movementdisorders.org/MDS-Files1/Education/Patient-Education/Ataxia/pt-Handouts-Ataxia-Russian-v1.pdf

11. Jonathan F. Marsden. Cerebellar ataxia. Balance. Gait, and Falls; 2018: 261-281.

Надійшла 12.03.2019

\section{Інформація про авторів}

Нагорний Ярослав Альвіанович

https://orcid.org/0000-0003-1414-2993

130287@i.ua

Національний університет фрізичного виховання і спорту України, 03150, Київ, вул. Фізкультури, 1
Information about the authors

Nagornyiy Yaroslav https://orcid.org/0000-0003-1414-2993 130287@i.ua

National University of Ukraine on Physical Education and Sport, 03150, Kyiv, Fizkultury st., 1 